\title{
Pengaruh Sikap Istri dan Suami Berdasarkan Kolose 3:18-19 Terhadap Kebahagiaan Keluarga
}

\author{
Hesekiel Siregar \\ Sekolah Tinggi Teologi Bethel Samarinda \\ Email: hesekielsiregar@sttbethelsamarinda.ac.id
}

\begin{abstract}
:
Family happiness is something longed for every husband and wife couple. The attitude shown by each wife or husband greatly influenced the realization of family happiness. This study aimed to determine the attitudes of wives and husbands based on Colossians 3: 18-19 on family happiness. This research was conducted at the Gereja Bethel Indonesia Keluarga Imamat Rajani Congregation Samarinda. This study used an explanatory - confirmatory method. The sample of this study were 73 married people. The results showed that: First, there was a significant influence on the wife's attitude towards her husband on family happiness. Second, there is no significant influence on the husband's attitude towards his wife on family happiness. Guidance for husbands and wives needs to be improved through teaching and sermons, so that husbands and wives can understand their respective roles as stated in Colossians 3: 18-19, so that the implementation of the program may increase family happiness.
\end{abstract}

Key Words: Husband's Attitude, Wife's Attitude, Family happiness.

\begin{abstract}
Abstrak:
Kebahagiaan keluarga menjadi dambaan bagi setiap pasangan suami dan istri. Sikap yang ditunjukkan masing-masing sitri atau suami sangat berpengaruh terhadap perwujudan kebahagiaan keluarga. Penelitian ini bertujuan untuk mengetahui sikap istri dan suami berdasarkan kolose 3:18-19 terhadap kebahagiaan keluarga. Penelitian ini dilakukan di gereja Bethel Indonesia jemaat Keluarga Imamat Rajani Samarinda. Penelitian ini menggunakan metode eksplanatori - konfirmatori. Sampel penelitian ini sebanyak 73 orang yang telah berkeluarga. Hasil penelitian menunjukkan bahwa: Pertama, terdapat pengaruh yang signifikan sikap istri kepada suami terhadap kebahagiaan keluarga. Kedua, tidak terdapat pengaruh yang signifikan sikap suami kepada istri terhadap kebahagiaan keluarga. Pembinaan terhadap suami dan istri perlu ditaingkatkan melalui pengajaran maupun kotbahkotbah, sehingga suami dan sistri dapat memahami peranannya masing-masing sebagaimana yang terdapat dalam Kolose 3:18-19, sehingga implementasi dari program tersebut dapat meningkatkan kebahagiaan keluarga.
\end{abstract}

Kata Kunci: Sikap Suami, Sikap Istri, Kebahagiaan Keluarga.

\section{Pendahuluan}

Kebahagiaan rumah tangga menjadi harapan bagi semua orang dan berupaya untuk mewujudkannya (Gea, 2019). Realita dalam kehidupan rumah tangga munculnya konflik menjadi hambatan dalam mewujudkan rumah tangga yang Bahagia. Bahkan konflik tersebut bisa berujung pada perceraian. Secara khusus pada kasus perceraian di Kalimantan Timur dapat dikategorikan tinggi. Menurut Kepala Dinas Kependudukan, Pemberdayaan Perempuan dan Perlindungan Anak (DKP3A) Kalimantan Timur, Halda 
Arsyad bahwa pada tahun 2018 angka perceraian mencapai 2.249 kasus dan pada tahun 2019 meningkat menjadi 7.803 kasus. Dari 7.803 kasus pada tahun 2019, menunjukkan bahwa Kota Samarinda menempati urutan yang tertinggi, yaitu mencapai 2.665 kasus perceraian (Putra, 2020). Meskipun kasus perceraian ini mencakup semua golongan agama, termasuk ada diantaranya terjadi pada umat Kristen. Melihat fenomena ini, memberikan gambaran bahwa banyak diantaranya rumah tangga tidak mengalami kebahagiaan yang berdampak pada kehencuran.

Kehidupan rumah tangga identik dengan ribut dan rukun (Ismail, 2007). Artinya konflik selalu ada dan tidak bisa dihindari, namun satu sisi juga adanya situasi rukun yang membuat kehidupan rumah tangga tetap bahagia. Keinginan bercerai sesungguhnya suatu akibat bukan karena kegagalan dalam membangun relasi (Schafer \& Ross, 2012). Artinya dalam suatu relasi yang terbangun antara suami dan istri berdampak pada keharmonisan dan kebahagiaan rumah tangga. Apabila hubungan tersebut identik dengan tidak terbangun dengan baik yang berkepanjangan dapat pula berdampak pada kehancuran dan perceraian. Peran gereja tentunya sangat penting dalam memberikan pemahaman dan pengajaran dalam mewujudkan rumah tangga atau keluarga Kristen tetap bahagia meskipun menghadapi konflik dalam relasi yang terbangun. Kebahagiaan sebagai harapan yang harus diupayakan. Dalam upaya inilah, sikap antara suami dan istri serta seluruh anggota keluarga sangat berpengaruh dalam mewujudkan kebahagiaan.

Peran suami dan istri dalam menjaga keutuhan dan kebahagiaan keluarga sangatlah sentral. Upaya gereja pada pembinaan umat memang dilaksanakan, namun hanya sekedar insidental. Pembinaan seringkali dilakukan hanya pada sebatas konseling pra-nikah. Pembinaan ini dipandang masih kurang optimal, karena dalam kehidupan harihari banyak konflik yang terjadi di dalam kehidupan rumah tangga. Permasalaha suami istri dalam rumah tangga sangat kompleks yang perlu mendapat perhatian dalam pembinaan keutuhan, ketahanan dan kebahagiaan rumah tangga (Sihombing, Sitopu, \& Sitorus, 2020).

Relasi suami istri semestinya menempatkan pada peran dan fungsi masing-masing serta sinergisitas dalam membangun kehidupan rumah tangga. Kesadaran akan tanggungjawab sebagai bagian dalam upaya mewujudkan kehidupan rumah tangga yang bahagia. Tidak memandang rendah pasangan, keadaan ekonomi dan saling memperhatikan menjadi bagian dari kunci mewujudkan keluarga bahagia. Peran masingmasing sesuai dengan fungsinya akan meminimalkan konflik dalam rumah tangga, sehingga kebahagiaan akan selalu dirasakan dan dialami oleh keseluruhan anggota keluarga. Di dalam kehidupan pernikahan atau rumah tangga tidak dapat dipungkiri munculnya konflik dikarenakan dua orang yang berbeda disatukan. Perbedaan-perbedaan memiliki potensi menimbulkan konflik. Namun, di dalam kehidupan rumah tangga harus 
memahami tujuannya, sehingga mampu mempertahankan keharmonisan dan mewujudkan kebahagiaan.

Menurut Wowon (2004) bahwa tujuan perkawinan untuk membentuk keluarga yang penuh dengan damai, aman, rukun dan sejahtera, sehingga rumah tangga terus dapat berlanjut sampai maut yang memisahkan. Banyak keluarga yang kelihatannya dari tampak luarnya Bahagia tetapi sesungguhnya sangat buruk dalam hubungan yang dijalaninya. Hubungan cinta kasih yang dibangun sebagai suatu sistem yang buruk (Susabda, 2004). Kondisi demikian tidak akan bertahan kuat yang dapat berdampak pada ketidakbahagiaan dalam berumah tangga.

Sikap suami dan istri yang tidak pada orientasi pada diri sendiri dan kesenangannya, melainkan saling menghargai, memperhatikan serta menunjukkan tanggungjawab yang tinggi menjadi kunci bagi perwujudan kebahagiaan rumah tangga. Sikap suami isteri yang kurang komunikasi dan juga kepada anak-anaknya, sehingga membuat kurangnya kepercayaan satu sama lain. Kurang mengenal pribadinya masingmasing, serta kesibukan membuatnya kurang memiliki waktu dalam kebersamaan, sehingga kurangnya perhatian dan kasih sayang. Suami sebagai kepala rumah tangga tidak hanya memiliki tugas mencari nafkah dalam memenuhi kebutuhan keluarga, melainkan juga berperan mengayomi, membimbing istri dan anak-anak pada jalan yang benar sesuai dengan nilai-nilai agama. Suami menjadi sahabat bagi istri yang mampu meringankan tugas istri dan memiliki waktu kebersamaan bersama anak-anak. Peran pendampiungan suami bagi istri dan anak-anak akan menjadi ketahanan dalam kehidupan rumah tangga. Demikian pula istri berperan membantu dan meringankan tugas suami. Menjadi sahabat yang menyenangkan dalam diskusi dan serta menjadi pendorong bagi kemajuan serta kesuksesan suami dalam tugasnya (Putri \& Lestari, 2015).

Kebahagiaan keluarga tidak hanya ditentukan dari orangtua, baik peran dari suami maupun istri, namun juga peran dari anak-anak. Relasi orangtua dan anak sangat berpengaruh pada pembentukan nilai-nilai pada diri anak dan mempengaruhi perkembangannya, baik secara psikologis, spiritual, moral dan sosial. Kenakalan anak dapat disebabkan karena hubungan yang kurang harmonis antara anak dengan orangtua, komunikasi yang buruk, kurangnya kasih sayang, keluarga yang kurang harmonis, selain faktor pergaulan anak itu sendiri. Keluarga yang kurang harmonis dapat berdampak pada kenakalan anak, sehingga mempengaruhi kebahagiaan keluarga. Sedangkan hubungan yang dekat antara orangtua dengan anak, yang dibangun melalui perhatian dan kasih sayang akan memberikan kontribusi dalam pewujudan kebahagiaan keluarga (Tari \& Tafonao, 2019).

Kolose 3;18-19 menjadi gambaran bagi setiap anggota keluarga, baik suami maupun istri dalam mewujudkan kehidupan rumah tangga sesuai dengan kehendak Kristus. Peran masing-masing yang dilakukan dengan baik dan penuh tanggungjawab, 
menjadi sahabat yang saling mengasihi, saling menghargai, tidak berlaku kasar, saling membantu serta memberikan perhatian menjadi kekuatan dalam mewujudkan keluarga bahagia. Permasalahan dalam penelitian ini dirumuskan sebagai berikut: adakah pengaruh sikap suami dan isteri berdasarkan Kolose 3:18-19 terhadap kebahagiaan keluarga? Sedangkan tujuan dari penelitian ini untuk mendapatkan gambaran atas sikap suami dan sikap istri dan kecenderungan kebahagiaan keluarga serta pengaruh sikap setiap anggota keluarga tersebut terhadap kebahagiaan keluarga.

\section{Metode}

Metode penelitian yang dipergunakan dalam penelitian ini adalah survei dengan pendekatan eksplanatori - konfirmatori (Sasmoko, 2009). Kerlinger dalam Sugiyono (Sugiyono, 2017) menjelaskan bahwa penelitian survei adalah penelitian yang dilakukan pada populasi namun data yang digunakan merupakan dari sampel yang diambil dari populasi, kemudian hasilnya diberlakukan pada populasi. Menggunakan eksplanatori karena penelitian melakukan ekplorasi secara mendalam dalam pencarian makna dari sikap istri dan suami berdasarkan Kolose 3:18-19. Sedangkan konfirmatori bertujuan untuk pengujian atau mengkonfirmasi (Sasmoko, 2009) mengenai pengaruh sikap istri dan sikap suami terhadap terhadap kebahagiaan keluarga.

Penelitian ini dilakukan di Gereja Bethel Indonesi Keluarga Imamat Rajani Samarinda. Populasi penelitian ini jemaat yang telah berkeluarga dengan jumlah sampel sebanyak 73 orang. Teknik pengambilan sampel dengan menggunakan Simple random sampling" yaitu pengambilan sampel dari anggota populasi secara acak tanpa memperhatikan strata yang ada dalam anggota populasi.

Menurut Sasmoko (2009), ada tiga hal yang mendasar dalam menentukan kualitas temuan penelitian yaitu: pertama, dari aspek kualitas instrumen penelitian yang mengacu kepada construct theoretical; kedua, kejujuran surveyor dan peneliti; dan ketiga, kesesuaian teknik pengumpulan data dengan variabel penelitian, penetapan skala data, serta pendekatan yang tepat terhadap kalibrasi instrumen. Metode ini digunakan untuk memperoleh data primer, yaitu data yang diperoleh secara langsung dari subyek penelitian melalui pengisian kuesioner. Kuesioner yang dikembangkan menggunakan skala "Model Likert" dengan rentang skala data 1 sampai dengan 5.

Pengujian validitas instrumen dilakukan melalui validitas isi dan validitas butir. Dari jumlah item instrument sikap suami dari 40 butir instrument terdapat sebanyak 27 butir yang dinyatakan valid dengan koefisien reliabilitas sebesar 0,718. Instrumen sikap istri dikembangkan dari 36 butir instrument dan hasil pengujian validitas dinyatakan sebanyak 26 butir yang valid dengan koefisien reliabilitas serbesar 0,749. Sedangkan instrumen sikap anak dikembangkan dari 35 butir dan hasil analisis diperoleh butir yang 
valid sebanyak 18 butir dengan koefisien reliabilitas sebesar 0,673. Teknik analisis data dilakukan dengan analisis korelasi dan regresi sederhana.

\section{Hasil dan Pembahasan}

\section{Sikap Istri terhadap Suami}

Kolose 3:18 dalam teks Bahasa Indonesia Terjemahan Baru dinyatakan bahwa "Hai isteri tunduklah kepada suamimu sebagaimana seharusnya di dalam Tuhan,"

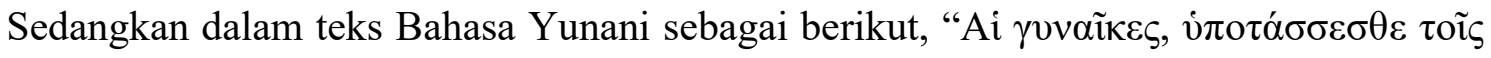

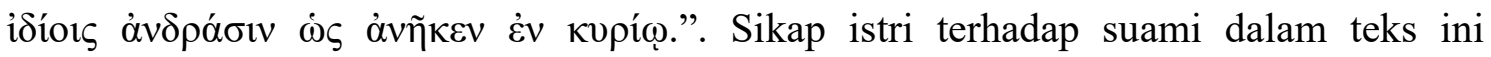
ditunjukkan dalam kata "tunduklah". Kata ini merupakan terjemahan dari kata dalam

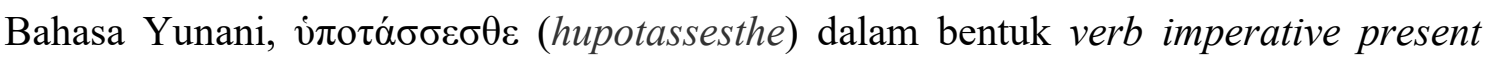

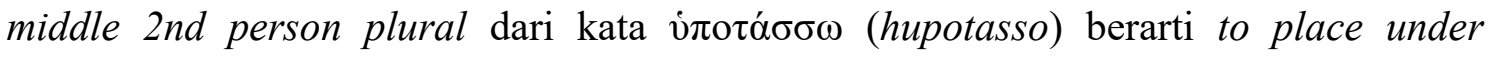
(menempatkan di bawah), to submit to one's control (untuk tunduk pada kendali seseorang, dalam konteks ini adalah suami), to obey to one's admonition or advice (untuk tunduk pada peringatan atau nasihat suami) (BibleWorks, 2018). Kata hupotasso bukan berarti ketertundukan yang mengandung unsur penaklukkan pada seluruh otoritas suami, sehingga berada pada keseluruhan kekuasaan suami. Kata "tunduklah" juga mengacu pada tunduk kepada miliknya sendiri. Artinya bahwa seseorang ketika hidup dalam rumah tangga, maka suami dan istri telah menjadi satu sehingga mereka bukan lagi dua, melainkan satu. Dalam konteks ini suami sebagai milik istri dengan juga istri sebagai milik suami. Ketertundukan istri sebagai bentuk ketertundukan pada miliknya sendiri. Kata hupotassō tidak digunakan pada penaklukan (subjugation), melainkan kata ini digunakan menunjuk pada penundukan (subordination). Tunduklah bukan berarti seorang istri ada dalam penaklukan suami, sehingga dirinya harus menerima seluruh perlakuan atau tindakan suami sebagai bentuk penaklukkan diri dari kesewenangan.

Kata hupotasso mendapat bentuk imperative, artinya "tunduklah" merupakan sesuatu yang sangat penting, disampaikan sebagai suatu kewajiban yang harus dilakukan. Menurut Mounce (2011) bahwa "tidak ada cara yang lebih kuat dalam bahasa Yunani untuk mengatakan kepada seseorang untuk melakukan sesuatu, daripada kata imperative, khususnya imperative orang kedua." Bentuk Present middle yang melekat pada kata ini juga menjadikan kata hupotasso sifatnya mengikat dan berlangsung terus menerus atau tanpa akhir. Jadi perintah untuk "tunduklah" sebagai suatu perintah yang harus dilakukan (dengan tegas tidak boleh dilanggar) oleh lawan bicara Rasul Paulus pada saat itu (istriistri) dan harus secara terus menerus dilakukannya.

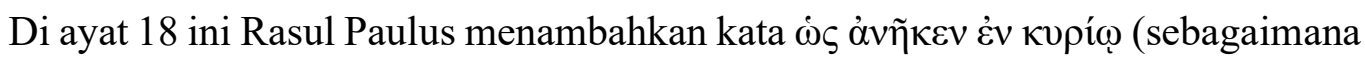
seharusnya di dalam Tuhan). Kata $\alpha \dot{\nu} \tilde{\eta} \kappa \varepsilon v$ (aneken) dengan bentuk indicative imperfect

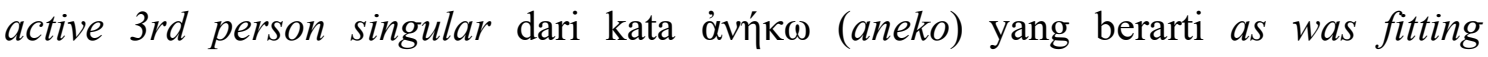
(sebagaimana mestinya atau seharusnya) (BibleWorks, 2018). Bentuk indicative 
imperfect menyiratkan bahwa kata ini merupakan suatu kata yang menunjukan tindakan kontinyu yang biasanya terjadi di masa lampau, namun peristiwa atau perilaku ini juga secara terus menerus dilakukan dengan muatan yang sama sampai saat ini. Kata active $3 r d$ person singular menunjukan bahwa pembicara (Rasul Paulus) sedang mengacu kepada para pelaku aneko yang dengan aktif melakukan hal yang dimaksudkannya. Sedangkan active artinya niat sendiri dari dalam diri sendiri (istri-istri) dengan kesungguhan. Kata aneko secara historis sering digunakan dalam filsafat Stoa yang menunjuk pada Tindakan atau perilaku yang sesuai dengan tatanan alamiah atau sebagaimana yang berlaku. Namun dalam konteks ini, Paulus menambahkan kata $\dot{\varepsilon} v$ кupí (en kurio) artinya "di dalam Tuhan". Artinya Paulus tidak mengambil makna tunduklah mengacu pada tatanan yang ada di masyarakat sebagaimana yang dimaksuk dalam filsafat Stoa, melainkan tunduk pada tatanan Tuhan. Ketertundukan yang dilakukan istri-istri sebagai suatu keharusan yang terus menerus dilakukan secara aktif yang bersumber dari keinginan atau niat dari diri sendiri dengan kesungguhan yang mendalam.

\section{Sikap Suami terhadap Istri}

Kolose 3:19 dalam teks Bahasa Indonesia Terjemahan Baru dinyatakan bahwa "Hai suami-suami, kasihilah isterimu, dan jangan berlaku kasar terhadap dia," Sedangkan

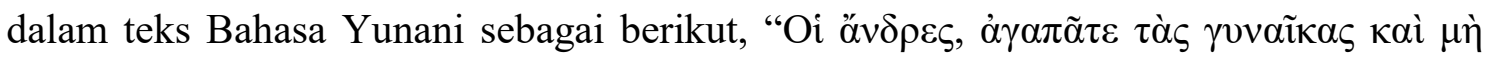
$\pi \iota \kappa \rho \alpha i ́ v \varepsilon \sigma \theta \varepsilon \pi \rho \grave{\varsigma} \varsigma \alpha$ $\tau \alpha \dot{c} \varsigma^{\prime}$. Sikap suami terhadap istri dalam teks ini ditunjukkan dalam kata "kasihilah". Kata terjemahan ini berasal dari kata dalam Bahasa Yunani à $\gamma \alpha \pi \tilde{\alpha} \tau \varepsilon$

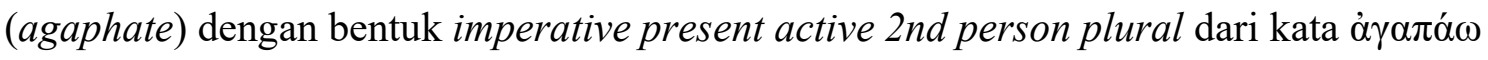
(agaphao) yang berarti to welcome (untuk disambut), to entertain (untuk dihibur), to be fond of (untuk disayangi), to love dearly (untuk dicintai), to be well pleased (untuk disenangkan), to be contented at (untuk dipuaskan) (BibleWorks, 2018). Kata agaphao mendapat bentuk imperative (Drewes, Haubeck, \& Siebenthal, 2011), artinya kasih suami kepada istri sebagai kewajiban yang harus dilakukan. Sedangkan dari bentuk active 2nd person plural menunjukkan rasul Paulus sedang memberikan perintah kepada para suami untuk mengasihi istri-istri. Bentuk active dari kata agaphao berarti suami-suami diperintahkan untuk selalu dan dengan kesungguhannya mengasihi istri, menyenangkan dan berupaya memuaskan hati istrinya melalui perilakunya dalam keseharian. Kasihilah istrimu menunjukkan bahwa kasih itu memang lahir dari kesadaran suami tanpa adanya rangsangan dari pihak luar. Dalam konteks ayat ini, mengasihi berarti suatu perintah agar setiap suami dengan keinginannya sendiri dan berasal dari dalam dirinya atau keinginannya sendiri untuk mengasihi istrinya, bersedia menyambutnya dengan kerelaan, tanpa syarat dan bersedia untuk menghibur serta menyenangkan dan memuaskan hatinya. 
Kata berlaku kasar merupakan kata $\pi$ « $\alpha$ íve $\sigma \theta \varepsilon$ (pikrainesthe) yang mendapat bentuk imperative present passive 2nd person plural dari kata kerja $\pi 1 \kappa \rho \alpha i v \omega$ (pikraino), yang berarti to make bitter, exasperate, render angry, indignant, to be embittered, irritated (membuat pahit, menjengkelkan, membuat marah, menjadi sakit hati) (BibleWorks, 2018). Kata pikrainesthe mendapat bentuk imperative (Drewes et al., 2011), artinya kata ini sangat penting yang disampaikan sebagai suatu kewajiban yang harus dilakukan, yaitu jangan membuat istri-istri menjadi marah, jengkel dan sakit hati. Bentuk present passive yang melekat pada kata menunjuk pada perintah yang memang dirangsang dari luar diri suami, dalam hal ini Rasul Paulus merangsang dan mendorong para suami untuk melakukannya terus menerus atau tanpa akhir. Perlu diingat, karena sebelum kata ini ada kata $\mu \grave{\eta}(m e)$, maka perintah yang disampaikan berubah menjadi larangan. Hal ini terjadi karena kata $\mu$ 门̀ berarti jangan, tidak boleh. Jadi dalam ayat ini, berlaku kasar atau menyebabkan hati (seorang istri) menjadi pahit adalah sebuah larangan yang disampaikan sebagai suatu perintah yang harus dilakukan (dengan tegas tidak boleh dilanggar) oleh lawan bicara Rasul Paulus pada saat itu (suami-suami) dan harus secara terus menerus dilakukan oleh mereka. Kata selanjutnya adalah $\pi \rho$ ó $\varsigma$ (pros) dalam ayat ini melekat pada kata oủiós (autas), maka ia mendapat kasus atau bentuk accusative. Ini berarti ia digunakan untuk menunjukan gerakan ke arah seseorang yang dalam hal ini kepada istri-istri.

Suami dalam kehidupan hari-harinya harus mengasihi istri yang tumbuh dari kesadaran dari dalam dirinya untuk selalu melakukan yang terbaik dalam menyenagkan hati istri. Sikap yang ditunjukkan bukan membuatnya sakit hati dan mengalami kekecewaan, melainkan membuanya disenangkan melalui sikap yang kita tampilkan dalam kehidupan hari-hari. Suami harus mengarahkan sikapnya yang baik kepada istri dengan memperlakukannya tidak kasar, menjengkelkan dan membuatnya merasakan kepahitan, melainkan menyenangkan hatinya. Dengan sikap yang demikian, suami akan mampu membangun kehidupan rumah tangga yang penuh kebahagiaan.

\section{Analisis Deskriptif Data Penelitian}

Berdasarkan análisis statistika deskriptif, diperoleh hasil sebagai berikut:

Descriptive Statistics

\begin{tabular}{|l|c|c|c|c|c|}
\hline & N & Minimum & Maximum & Mean & Std. Deviation \\
\hline Sikap Istri Kepada Suami & 73 & 90 & 125 & 113.37 & 8.917 \\
\hline Sikap Suami Kepada Istri & 73 & 97 & 135 & 116.71 & 10.051 \\
\hline Kebahagiaan Keluarga & 73 & 52 & 85 & 74.48 & 7.343 \\
\hline
\end{tabular}

Tabel 1. Analisis Data Deskriptif 
Berdasarkan pada tabel 1, bahwa untuk data sikap istri kepada suami diperoleh hasil perhitungan nilai rata-rata sebesar 113,37 dengan skor minimum sebesar 90 dan skor maksimum sebesar 125 dan standar deviasi sebesar 8,917. Berdasarkan sebaran data menunjukkan bahwa sebanyak 35 orang atau 47,95\% yang memperoleh skor di bawah rata-rata. Sedangkan sebanyak 38 orang atau 52,05\% yang memperleh skor di atas ratarata. Oleh karena diperoleh lebih dari 50\% responden yang menunjukkan bahwa sikap istri terhadap suami sudah baik yang memberikan gambaran telah menunjukkan sikap ketertundukannya kepada suami sebagaimana yang dimaksud dalam Kolose 3:18.

Hasil analisis data sikap suami kepada istri diperoleh hasil perhitungan nilai ratarata sebesar 116,71 dengan skor minimum sebesar 97 dan skor maksimum sebesar 135 dan standar deviasi sebesar 10,051. Berdasarkan sebaran data menunjukkan bahwa sebanyak 38 orang atau 52,05\% yang memperoleh skor di bawah rata-rata. Sedangkan sebanyak 35 orang atau 47,95\% yang memperleh skor di atas rata-rata. Oleh karena diperoleh kurang dari 50\% responden yang menunjukkan bahwa sikap suami terhadap istri belum sepenuhnya sesuai dengan harapan mengasihi dan berlaku tidak kasar kepada istri sebagaimana yang dimaksud dalam Kolose 3:19.

Hasil analisis data kebahagiaan keluarga diperoleh hasil perhitungan nilai ratarata sebesar 74,48 dengan skor minimum sebesar 52 dan skor maksimum sebesar 85 dan standar deviasi sebesar 7,343. Berdasarkan sebaran data menunjukkan bahwa sebanyak 32 orang atau 43,84\% yang memperoleh skor di bawah rata-rata. Sedangkan sebanyak 41 orang atau 56,16\% yang memperleh skor di atas rata-rata. Oleh karena diperoleh lebih dari $50 \%$ responden memperoleh skor rata-rata dan diatas rata-rata yang menunjukkan bahwa kebahagiaan keluarga cukup dirasakan dan dialami.

\section{Pengaruh Sikap Istri Kepada Suami terhadap Kebahagiaan Keluarga}

Hasil analisis korelasi dan regresi pengaruh sikap istri kepada suami terhadap kebahagiaan keluarga diperoleh hasil sebagai berikut:

Model Summary

\begin{tabular}{|l|r|r|r|r|}
\hline Model & R & R Square & $\begin{array}{c}\text { Adjusted R } \\
\text { Square }\end{array}$ & $\begin{array}{c}\text { Std. Error of } \\
\text { the Estimate }\end{array}$ \\
\hline 1 & $.553^{\mathrm{a}}$ & .306 & .296 & 6.162 \\
\hline
\end{tabular}

a. Predictors: (Constant), Sikap Istri Kepada Suami

Coefficients $^{\mathrm{a}}$

\begin{tabular}{|l|c|c|c|c|}
\hline Model & $\begin{array}{c}\text { Unstandardized } \\
\text { Coefficients }\end{array}$ & $\begin{array}{c}\text { Standardized } \\
\text { Coefficients }\end{array}$ & $\mathrm{T}$ & Sig. \\
\hline
\end{tabular}

H. Siregar, Pengaruh Sikap Istri dan Suami Berdasarkan Kolose 3:18-19 ..... 160 


\begin{tabular}{|l|l|r|r|r|r|r|}
\hline \multicolumn{2}{|c|}{} & \multicolumn{1}{|c|}{ B } & Std. Error & \multicolumn{1}{|c|}{ Beta } & & \\
\hline \multirow{3}{*}{1} & $($ Constant $)$ & 22.873 & 9.261 & & 2.470 & .016 \\
\cline { 2 - 7 } & $\begin{array}{l}\text { Sikap Istri Kepada } \\
\text { Suami }\end{array}$ & .455 & .081 & .553 & 5.589 & .000 \\
\hline
\end{tabular}

a. Dependent Variable: Kebahagiaan Keluarga

Tabel 2. Hasil Analisis Korelasi dan Regresi Pengaruh Sikap Istri kepada Suami terhadap Kebahagiaan Keluarga

Dari hasil analisis pada table 2 menunjukkan bahwa besarnya koefisien korelasi antara sikap istri kepada suami terhadap kebahagiaan keluarga sebesar 0,553 dengan koefisien determinansi varians sebesar 0,306 dengan koefisien sig. sebesar 0,000 yang berarti sangat signifikan. Hasil ini memberikan arti bahwa terdapat pengaruh yang signifikan sikap istri kepada suami terhadap kebahagiaan keluarga. Besarnya koefisien determinansi varians sebesar 0,306 memiliki arti bahwa sikap istri kepada suami memberikan pengaruh sebesar 30,6\% bagi perwujudan kebahagiaan keluarga, sedangkan sisanya sebesar 69,4\% dipengaruhi faktor lainnya. Hasil ini memberikan makna bahwa semakin baik sikap istri kepada suami, di mana dalam kehidupan hari-hari memiliki ketertundukan kepada suami sebagai wujud kasih dan kerendahan hatinya akan berdampak pada peningkatan kebahagiaan keluarga.

Diperoleh persamaan regresi $\hat{Y}=22,873+0,455 \mathrm{X}_{1}$ memberikan makna bahwa melalui satu program pembinaan kepada istri dalam kehidupan rumah tangga akan mampu meningkatkan kebahagiaan keluarga sebesar 0,455 pada konstanta 22,873. Dengan demikian, program pembinaan keluarga perlu dilakukan secara intens tidak hanya pada saat pembekalan dalam bimbingan pra-nikah, melainkan melalui program pengajaran, khotbah-khotbah pada ibadah raya akan mampu meningkatkan kebahagiaan keluarga.

\section{Pengaruh Sikap Suami Kepada Istri terhadap Kebahagiaan Keluarga}

Hasil analisis korelasi dan regresi pengaruh sikap suami kepada istri terhadap kebahagiaan keluarga diperoleh hasil sebagai berikut:

Model Summary

\begin{tabular}{|l|r|r|r|r|}
\hline Model & \multicolumn{1}{|c|}{$\mathrm{R}$} & R Square & $\begin{array}{c}\text { Adjusted R } \\
\text { Square }\end{array}$ & $\begin{array}{c}\text { Std. Error of } \\
\text { the Estimate }\end{array}$ \\
\hline 1 & $.056^{\mathrm{a}}$ & .003 & -.011 & 7.383 \\
\hline
\end{tabular}

a. Predictors: (Constant), Sikap Suami Kepada Istri 
Coefficients $^{\mathrm{a}}$

\begin{tabular}{|c|c|c|c|c|c|c|}
\hline \multirow{2}{*}{\multicolumn{2}{|c|}{ Model }} & \multicolumn{2}{|c|}{$\begin{array}{l}\text { Unstandardized } \\
\text { Coefficients }\end{array}$} & \multirow{2}{*}{$\begin{array}{l}\text { Standardized } \\
\text { Coefficients }\end{array}$} & \multirow[t]{2}{*}{$\mathrm{T}$} & \multirow[t]{2}{*}{ Sig. } \\
\hline & & B & Std. Error & & & \\
\hline \multirow[b]{2}{*}{1} & (Constant) & 79.277 & 10.141 & & 7.818 & .000 \\
\hline & $\begin{array}{l}\text { Sikap Suami } \\
\text { Kepada Istri }\end{array}$ & -.041 & .087 & -.056 & -.475 & .636 \\
\hline
\end{tabular}

a. Dependent Variable: Kebahagiaan Keluarga

Tabel 3. Hasil Analisis Korelasi dan Regresi Pengaruh Sikap Suami Kepada Istri terhadap Kebahagiaan Keluarga

Dari hasil analisis pada tabel 3 menunjukkan bahwa besarnya koefisien korelasi antara sikap suami kepada istri terhadap kebahagiaan keluarga sebesar 0,056 dengan koefisien determinansi varians sebesar 0,003 dengan koefisien sig. sebesar 0,636 yang berarti tidak signifikan. Hasil ini memberikan arti bahwa tidak terdapat pengaruh yang signifikan sikap suami kepada istri terhadap kebahagiaan keluarga. Besarnya koefisien determinansi varians sebesar 0,003 memiliki arti bahwa sikap suami kepada istri hanya mampu memberikan pengaruh sebesar $0,3 \%$ yang tidak signifikan bagi perwujudan kebahagiaan keluarga. Hasil ini memberikan makna bahwa upaya meningkatkan sikap suami kepada istri tidak memberikan pengaruh yang signifikan bagi peningkatan kebahagiaan keluarga.

Diperoleh persamaan regresi $\hat{Y}=79,277$ - 0,041 $\mathrm{X}_{2}$ memberikan makna bahwa melalui satu program pembinaan kepada suami dalam kehidupan rumah tangga tidak berdampak secara signifikan pada peningkatan kebahagiaan rumah tangga. Justru program perbaikan kurang menjadi efektif karena dapat menurunkan kebahagiaan keluarga sebesar -0,041 pada konstanta 79,277. Dengan demikian, program pembinaan kepada suami perlu dikaji dengan baik, yang harus memperhatikan berbagai aspek-aspek yang dioptimalkan paling efektif untuk dapat mewujudkan kebahagiaan keluarga.

\section{Pembahasan}

Keluarga bahagia menjadi harapan bagi semua orang. Kebahagiaan tidak datang dengan sendirinya melainkan harus diupayakan oleh semua anggota keluarga. Dalam upaya inilah ditentukan dari sikap yang ditampilkan oleh masing-masing anggota keluarga yang mempengaruhi relasi yang terbangun di antara anggota keluarga. Keluarga bahagia apabila antara anggota saling mengasihi dan hidup rukun (Mendrofa, 2020). Sebagaimana dalam Kolose 3:18-21, kebahagiaan akan dapat terwujud ketika suami dan istri melakukan peran dan fungsinya masing-masing. Saling mengasihi, menghormati, 
sebagai sahabat yang menolong dan memberikan perhatian serta bersikap yang baik antara yang satu dengan yang lainnya.

Hasil penelitian ini menunjukkan bahwa sikap istri kepada suami yang paling berpengaruh terhadap peningkatan kebahagiaan keluarga. Dengan sikap tunduk dan mengasihi kepada suaminya, seorang istri dapat menciptakan suasana harmonis yang meliputi seluruh segi dalam rumah tangga. Karena dengan demikian, menciptakan landasan yang kokoh dalam rumah tangga, tercipta suatu relasi yang harmonis, penuh kasih mesra, sukacita dan damai sejahtera dalam menjalani kehidupan rumah tangga (Gea, 2019). Terciptanya suasana harmonis dalam rumah tangga akan menimbulkan suatu iklim yang baik, anak-anak mendapatkan perhatian dan kasih sayang yang semestinya mereka dapatkan, tumbuh dengan baik, serta takut akan Tuhan sehingga menjadi suatu keluarga yang diberkati oleh Tuhan dan dapat menjadi teladan dalam lingkungan sosial.

Hasil penelitian ini sejalan dengan penelitian Octvia dan Sumule bahwa seorang istri memiliki peranan yang penting dan besar bagi keluarga. Peranan tersebut yang akan membuat keluarga atau rumah tangganya memiliki kebahagiaan sebagaimana yang diharapkan. Melalui peran istri yang melayani, memberikan perhatian, memberikan dukungan dan menunjukkan ketertundukan kepada suami memiliki pengaruh yang besar bagi perubahan sikap suami menjadi lebih baik dan menjadi alat bagi Tuhan menghadirkan kebahagiaan keluarga. (Octavia \& Sumule, 2019) Peranan istri sangatlah besar bagi keluarga. Melalui sikap yang baik, menyenangkan suami dan memiliki ketertundukan yang menggembarkan kerendahan hatinya akan mampu mengubahkan sikap suami dan anggota keluarganya dalam mewujudkan kebahagian keluarga.

\section{Kesimpulan}

Peneilitian ini memberikan kesimpulan bahwa sikap istri kepada suami memiliki pengaruh yang signifikan bagi perwujudan kebahagiaan keluarga. Istri memiliki peran yang sentral dalam membuat keluarganya bahagia. Melalui sikap ketertundukan istri yang menunjukkan sikap menghormati suami, dan kesediaannya menjadi penolong dan sahabat membuatnya memiliki kekuatan dalam memberikan pengaruh pada perubahan sikap suami. Ketertundukannya inilah yang akan membuat suami bukan menguasai melainkan penuh dengan kasih dan berupaya membahagian istri dengan memenuhi keinginan serta kepuasan istri.

Melalui ketertundukan istri membuat suami lebih bisa menerima dan memenuhi harapan istri bagi perwujudan keluarga yang bahagia. Kasih yang diberikan suami memang karena kesadaran dan dorongan dari dalam dirinya untuk memuaskan orang yang dikasihinya serta menerimanya dengan baik. Kasih tersebut yang menggerakan dirinya untuk tidak memperlakukan istri secara kasar, tidak menyakiti, tidak membuat jengkel dan marah. 
Melalui hasil penelitian ini, diharapkan menjadi stimulus bagi gereja untuk meningkatkan program pelayanan pembinaan kepada pasangan suami istri agar dapat berperan sesuai dengan fungsinya masing-masing. Pembinaan keluarga secara khusus bagi suami istri tidak hanya dilakukan pada saat bimbingan pra-nikah melainkan secara kontinya melalui program pengajaran maupun kotbah-kotbah tentang kelauarga.

\section{Daftar Rujukan}

BibleWorks. (2018).

Drewes, B. F., Haubeck, W., \& Siebenthal, H. von. (2011). Kunci Bahasa Yunani Perjanjian Baru. Jakarta: BPK Gunung Mulia.

Gea, S. (2019). Konsep Tunduk dan Mengasihi Berdasarkan Kolose 3:18-19 sebagai Landasan bagi Keutuhan Rumah Tangga kristen di GPdI Filadelfia. Voice of HAMI, 2(1), 60-77. Retrieved from http://stthami.ac.id/ojs/index.php/hami/article/view/6

Ismail, A. (2007). Selamat Ribut Rukun: 33 Renungan tentang Keluarga. Jakarta: BPK Gunung Mulia.

Mendrofa, A. (2020). Familly. HAGGADAH Jurnal Teologi Dan Pendidikan Kristen, 1(1), 1-16. Retrieved from http://sttmwc.ac.id/e-journal/index.php/haggadah

Mounce, W. D. (2011). Basic Of Biblical Greek-Dasar-Dasar Bahasa Yunani Biblika. Malang: Literatur SAAT.

Octavia, Y., \& Sumule, L. (2019). Konsep Tentang Istri Kristen Berdasarkan Surat 1 Petrus 3:1-7 Dan Implikasinya Bagi Istri Kristen Masa Kini. Repository STT Jaffray, 1(4), 231-238.

Putra, E. P. (2020). Pemprov Kaltim Berupaya Tekan Angka Perceraian yang Naik. Republika.Co.Id. Retrieved from https://republika.co.id/berita/qiktgw484/pemprovkaltim-berupaya-tekan-angka-perceraian-yang-naik

Putri, D. P. K., \& Lestari, S. (2015). Pembagian Peran Dalam Rumah Tangga pada pasangan suami istri Jawa. Jurnal Penelitian Humaniora, 16(1), 72-85. https://doi.org/https://doi.org/10.23917/humaniora.v16i1.1523

Sasmoko. (2009). Metode Penelitian dan Analisis Data. Jakarta: Media Plus.

Schafer, R., \& Ross, F. A. (2012). Bercerai Boleh atau Tidak. Jakarta: BPK Gunung Mulia.

Sihombing, H., Sitopu, E., \& Sitorus, H. (2020). Desain Bahan Pembinaan Suami-Istri untuk Ketahanan Keluarga Warga Gereja. Immanuel Jurnal Teologi Dan Pendidikan Kristen, 1(2), 110-131. https://doi.org/10.46305/im.v1i2.17

Sugiyono. (2017). Metode Penelitian Kebijakan, Pendekatan Kuantitatif, Kualitatif, Kombinasi, $R \& D$ dan Penelitian Evaluasi. Bandung: ALFABETA.

Susabda, Y. (2004). Pembinaan Keluarga Kristen. Bandung: Mitra Pustaka. 
Tari, E., \& Tafonao, T. (2019). Pendidikan Anak dalam Keluarga Berdasarkan Kolose 3:21. Kurios: Jurnal Teologi Dan Pendidikan Agama Kristen, 5(1), 24-35. https://doi.org/https://doi.org/10.30995/kur.v5il.93

Wowon, C. (2004). Pandangan Sosial Agama. Jakarta: CV. Nitra Kencana Buana. 